228

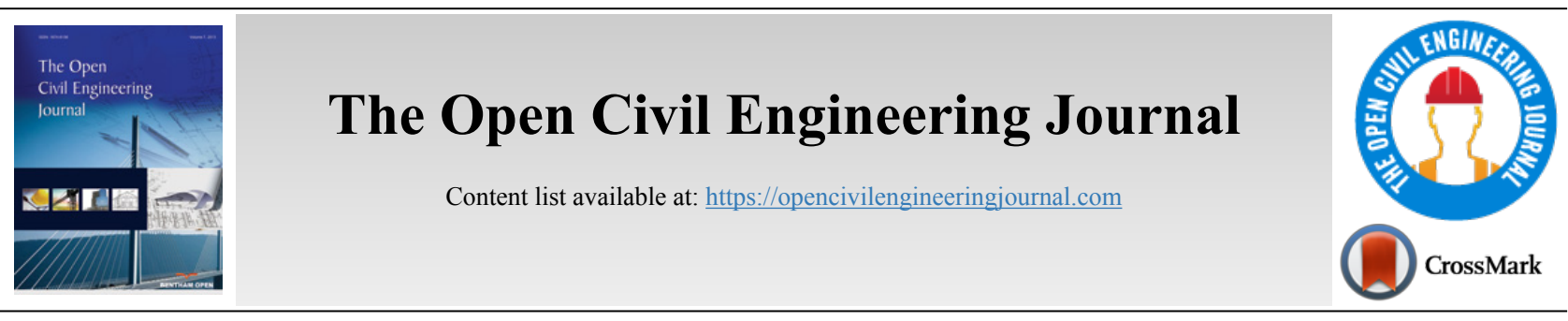

RESEARCH ARTICLE

\title{
Risk Factors Affecting Ground Improvement Work in the Gulf Corporation Council Countries
}

\author{
Bashar Tarawneh $^{1, *}$ and Khaled Al Ajmi ${ }^{2}$ \\ ${ }^{l}$ Civil Engineering Department, The University of Jordan, Amman, Jordan \\ ${ }^{2}$ Construction Training Institute, The Public Authority for Applied Education and Training, Adailiyah, Kuwait
}

\begin{abstract}
:
Aim:

This research aims to identify the risk factors related to ground improvement projects in the Gulf Corporation Council Countries (GCC).

Background:

Investigating and identifying those factors are essential to avoid schedule delay, cost overruns, diminished quality, and failure to achieve the project design requirements.

Methods:

A questionnaire was used to prioritize the possible risk factors that influence the ground improvement projects in the GCC.

Results:

Data were collected using a questionnaire completed by 120 respondents who work in the ground improvement industry in the GCC, including geotechnical engineers, technical managers, operation managers, project engineers, and project managers. Participants were asked three questions for each risk factor. Questions were about the impact, probability, and detection of the risk factor. Responses were analyzed using descriptive statistics, Responses' Score (R.S.), and Risk Priority Number (RPN).

\section{Conclusion:}

Five risk factors were included in the questionnaire, namely, site investigation, ground improvement technique, environmental conditions, ground improvement design, and ground improvement performance criteria. This paper also presents detailed recommendations to mitigate each risk factor.
\end{abstract}

Keywords: Ground improvement, Risk assessment, GCC, Risk factors, Desert sand, Site, Investigation.

\begin{tabular}{l|l|l|r} 
Article History & Received: May 24, 2020 & Revised: July 9, 2020 & Accepted: July 26, 2020
\end{tabular}

\section{INTRODUCTION}

Ground improvement work has become an important component of most construction projects in the Gulf Corporation Council Countries (GCC). Because the majority of the Arabian Peninsula is covered by fine loose desert sandy soils that become denser with depth and change to silty sands, the soil should be improved before construction to mitigate liquefaction and meet the foundations' bearing capacity and settlements requirements. Most popular ground improvement

\footnotetext{
* Address correspondence to this author at Civil Engineering Department, The University of Jordan, Amman, Jordan; Tel: +962-79-754-9696;

E-mail: btarawneh@ju.edu.jo
}

techniques in the GCC include dynamic compaction, dynamic replacement, stone columns, and rapid impact compaction. Ground improvement work is usually the first task of any construction project and dominates the foundations' type. Therefore, any problems with the ground improvement technique may lead to project delay, influence the quality, and increase the cost.

Ground improvement specialty contractors customarily perform ground improvement work. General contractors and owners usually outsource the ground improvement work to these specialty contractors. They prefer to outsource this task on a lump-sum basis to pass the responsibility of achieving 
project design requirements to the ground improvement contractors.

When pricing this type of work, ground improvement contractors are required to select the feasible ground improvement technique based on the soil investigation results. They are required to provide a ground improvement design to meet the ground improvement performance criteria. They are required to pay attention to any environmental issues, as well. Ground improvement contractors should perform their due diligence and risk assessment before pricing this type of work. Bidding on such work has risks, especially when dealing with the natural ground.

The goal of this research is to identify risk factors associated with ground improvement projects in the GCC. It is essential to investigate and identify those factors to meet schedules and budgets, preserve quality, and accomplish the foundation's design requirements. A course of action is proposed to deal with each risk factor before it occurs. A questionnaire was used to prioritize the possible risk factors in the GCC's ground improvement projects to achieve the goal of this research. Data were collected from this questionnaire, which was completed by 120 respondents who work in the GCC's ground improvement industry: geotechnical engineers, technical managers, operation managers, project engineers, and project managers. Responses were analyzed using descriptive statistics, Responses' Score (R.S.), and Risk Priority Number (RPN). Recommendations are provided below that can mitigate each risk factor.

\section{METHODS}

\subsection{Literature Review}

Recently, intensive research and development have concentrated on project risk management. Risk management can be defined as "a systematic way of looking at areas of risk and consciously determining how each should be treated. It is a management tool that aims at identifying sources of risk and uncertainty, determining their likelihood of occurrence, their impact, and developing appropriate management responses" [1].

Menezes et al. [2] defined risk assessment as an activity that involves two processes: risk identification, which aims to raise all the existing possibilities and events in a project, and risk analysis, which characterizes and prioritizes the identified risks to help decision-makers.

All projects face potential problems in the form of events or factors called risks, which are known to influence the time frame, budget, and quality of projects [3]. However, all risks involve both threats and opportunities [4]. The risk identification and analysis process help decision-makers to make a judgment before problems occur. There are many forms of response to identified risks, such as avoidance, reduction, or transfer [5]. Risk assessment is based on models of phenomena, events, and systems of interest, and a model often arises in consideration of the quality and reliability of the assessment but with different meanings [6].

Failure to implement standard risk management methods in the construction industry of the GCC region leads to construction projects that suffer from poor performance, delays, disputes, and claims. To design a standard risk management model, there is a need for an in-depth study of the construction environment to lay down the foundation for designing a standard construction risk management model in the future [7].

Ceric et al. [8] implemented the Analytical Network Process for assessing risk in sustainable ground improvement. Sensitivity analyses had shown stable decision-making results. Tarawneh [9] presented a decision tree to select the appropriate ground improvement technique in the Arabian Gulf Region. Altoryman [7] presented a study to identify and assess risk factors during the construction phase of projects in the Gulf region, focusing on two countries, the State of Kuwait and the Kingdom of Bahrain. The risk factors were identified and assessed, and responsibly shares were allocated to construction parties: clients, consultants, and contractors.

\subsection{Questionnaire}

\subsubsection{Questionnaire Design}

A nine-step procedure developed by Crawford [10] was used to design the questionnaire. The steps involved these: 1) decide on the information required; 2) define the target respondents; 3) select the method(s) of reaching the respondents; 4) determine question content; 5) word the questions; 6) sequence the questions; 7) check questionnaire length; 8) pretest the questionnaire; and 9) develop the final questionnaire. Closed-ended questions, which provide a set of answers from which the respondent must choose, were used. This type of question is easier and quicker for respondents to answer and makes the answers of different respondents easily compared, coded, and analyzed.

The target respondents were ground improvement specialists in the GCC (geotechnical engineers, technical managers, operation managers, project engineers, and project managers). To easily reach the target respondent, an online questionnaire was used. A link to the questionnaire was sent via e-mail to each target respondent.

The questionnaire was pretested by five ground improvement expert specialists in the GCC. Pretesting and piloting can help identify questions that do not make sense to participants, reduce measurement error, reduce respondent burden, determine whether or not respondents are interpreting questions correctly, and ensure that the order of questions is not influencing the way a respondent answers. A pretest, then, is a critical examination of the survey instrument that will help determine if the survey will function properly as a valid and reliable tool [11].

\subsubsection{Risk Factors}

Four risk factors were proposed to be included in the questionnaire: site investigation, ground improvement design, environmental conditions, and ground improvement technique.

During the pretesting stage of the questionnaire, all ground improvement experts agreed with the suggested risk factors. In addition, two of them suggested including the ground imp- 
rovement performance criteria. Their rationale was that some owners might require strict performance criteria to accept the work, which may cause a delay in the project or a change in the ground improvement technique. For example, some owners require field load tests, but others may require settlement calculations using a Standard Penetration Test (SPT), Cone Penetration Test (CPT), and Pressuremeter Test (PMT) data. This risk factor was added to the list, so the total number of risk factors is five. Some experts suggested a different order of the questions. After addressing all comments, the final questionnaire, presented in Table 1, was crafted. As shown in Table 1, participants were asked three questions for each risk factor. Questions were about the impact, probability, and detection of the specific risk factor. Participants were given the option to answer from " $1=$ very low" to " $5=$ very high," as shown in Table 1. Impact, probability, and detection meanings are discussed below.

\section{$\underline{\text { 2.2.2.1. Impact }}$}

Participants were asked to rank the impact of the risk factor, in case of happening, from "very low impact=1" for the risk factor with a minimal impact, ascending to "low impact $=2$,"

"moderate impact=3," "high impact=4," and "very high impact $=5$ " for the risk factor with the highest impact.

\subsubsection{Probability}

Participants were asked to rank the probability of the risk factor occurrence from "very low probability=1" for the risk factor with a minimal probability to happen and ascending to "low probability=2," "moderate probability=3," "high probability $=4$," and "very high probability $=5$."

\subsubsection{Detection}

Participants were asked to rank the ability to detect the risk factor from "very low detection=1" for the risk factor with a minimum detection, ascending to "low detection=2," "moderate detection=3," "high detection=4," and "very high detection=5."

\subsubsection{Reliability and Validity}

Reliability means that if anyone else were to use the same procedure to collect data at a different time under comparable conditions, they would get the same results [12]. There are several ways to test reliability, such as test-retest, the internal consistency method (Cronbach's coefficient alpha), the splithalf method, and the parallel-form method [13]. In this research, Cronbach's coefficient alpha $(\alpha)$ test was used to check the reliability of the collected data.

$\alpha$ is an estimate of the internal consistency associated with the scores that can be derived from a scale or a composite score. In the absence of reliability, it is impossible to have any validity associated with the scores of the scale. Based on the 15 questions provided in Table $1, \alpha=0.83$, which means that $83 \%$ of the variability in composite scores, by combining those 15 items, would be considered an internally reliable variance. Thus, the questionnaire is considered reliable.

Validity refers to "the problem of whether the data collected is a true picture of what is being studied" [12]. Questionnaire content validity is frequently evaluated by the researcher [14]. The steps taken in designing the questionnaire helped in checking the content validity. That is, the risk factors included in the questionnaire were checked by several practitioners during the review process, and a pilot test was carried out before the questionnaire was finalized, as mentioned in the questionnaire design section of this paper.

\section{RESULTS AND DISCUSSION}

Data were collected using a questionnaire completed by 120 respondents who work in the ground improvement industry in the GCC, including geotechnical engineers, technical managers, operation managers, project engineers, and project managers. Details about respondents such as country, years of experience, affiliation, and role are provided in Figs (1-4), respectively. Responses were analyzed using descriptive statistics, Responses' Score (R.S.), and Risk Priority Number (RPN).

Table 1. Questionnaire.

\begin{tabular}{|c|c|c|c|c|c|c|}
\hline \multirow{2}{*}{$\begin{array}{c}\text { Risk } \\
\text { Factor } \\
\text { No. }\end{array}$} & \multirow{2}{*}{ Risk Factor } & \multirow{2}{*}{ Question No. } & \multirow{2}{*}{ Question } & \multicolumn{3}{|c|}{ Answer Options } \\
\hline & & & & Impact & Probability & Detection \\
\hline \multirow{3}{*}{ F.1 } & \multirow{3}{*}{ Site investigation } & F.1.1 & $\begin{array}{l}\text { What is the impact of site investigation on ground improvement } \\
\text { projects? }\end{array}$ & 1 to 5 & - & - \\
\hline & & F.1.2 & What is the probability of site investigation to be a risk factor? & - & 1 to 5 & - \\
\hline & & F.1.3 & What is the ability to detect site investigation as a risk factor? & - & - & 1 to 5 \\
\hline \multirow[t]{3}{*}{ F.2 } & \multirow{3}{*}{$\begin{array}{c}\text { Ground improvement } \\
\text { design }\end{array}$} & F.2.1 & $\begin{array}{l}\text { What is the Impact of ground improvement design on any ground } \\
\text { improvement project? }\end{array}$ & 1 to 5 & - & - \\
\hline & & F.2.2 & $\begin{array}{l}\text { What is the probability that ground improvement design can be a } \\
\text { risk factor? }\end{array}$ & - & 1 to 5 & - \\
\hline & & F.2.3 & $\begin{array}{l}\text { What is the ability to detect the ground improvement design as a } \\
\text { risk factor? }\end{array}$ & - & - & 1 to 5 \\
\hline
\end{tabular}




\begin{tabular}{|c|c|c|c|c|c|c|}
\hline \multirow[t]{3}{*}{ F.3 } & \multirow{3}{*}{$\begin{array}{l}\text { Environmental } \\
\text { conditions }\end{array}$} & F.3.1 & $\begin{array}{l}\text { What is the impact of environmental conditions on any ground } \\
\text { improvement project? }\end{array}$ & 1 to 5 & - & - \\
\hline & & F.3.2 & $\begin{array}{l}\text { What is the probability that environmental conditions can be a risk } \\
\text { factor? }\end{array}$ & - & 1 to 5 & - \\
\hline & & F.3.3 & $\begin{array}{l}\text { What is the ability to detect environmental conditions as a risk } \\
\text { factor? }\end{array}$ & - & - & 1 to 5 \\
\hline \multirow[t]{3}{*}{ F.4 } & \multirow{3}{*}{$\begin{array}{c}\text { Ground improvement } \\
\text { technique }\end{array}$} & F.4.1 & $\begin{array}{l}\text { What is the impact of the used ground improvement technique on } \\
\text { any ground any ground improvement project? }\end{array}$ & 1 to 5 & - & - \\
\hline & & F.4.2 & $\begin{array}{l}\text { What is the probability that the used Ground Improvement } \\
\text { Technique can be a risk factor? }\end{array}$ & - & 1 to 5 & - \\
\hline & & F.4.3 & $\begin{array}{l}\text { What is the ability to detect the used ground improvement } \\
\text { technique as a risk factor? }\end{array}$ & - & - & 1 to 5 \\
\hline \multirow[t]{3}{*}{ F.5 } & \multirow{3}{*}{$\begin{array}{c}\text { Ground } \\
\text { Improvement } \\
\text { Performance Criteria }\end{array}$} & F.5.1 & $\begin{array}{l}\text { What is the impact of the ground Improvement performance criteria } \\
\text { on any ground improvement project? }\end{array}$ & 1 to 5 & - & - \\
\hline & & F.5.2 & $\begin{array}{l}\text { What is the probability that the ground improvement performance } \\
\text { criteria can be a risk factor? }\end{array}$ & - & 1 to 5 & - \\
\hline & & F.5.3 & $\begin{array}{l}\text { What is the ability to detect the ground improvement performance } \\
\text { criteria as a risk factor? }\end{array}$ & - & - & 1 to 5 \\
\hline
\end{tabular}

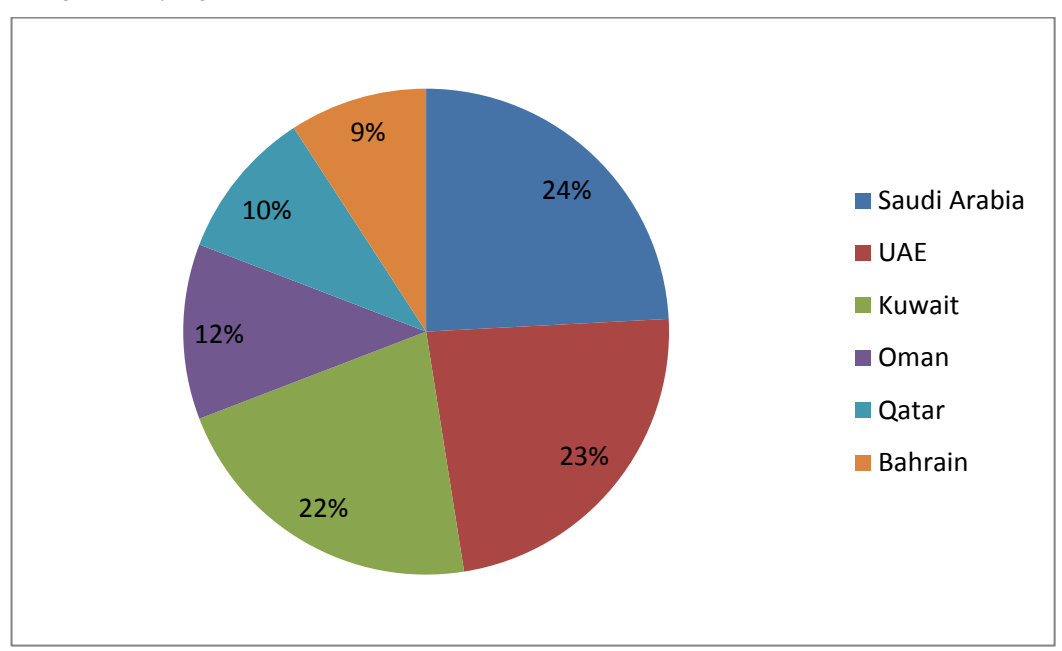

Fig. (1). Respondents by country.

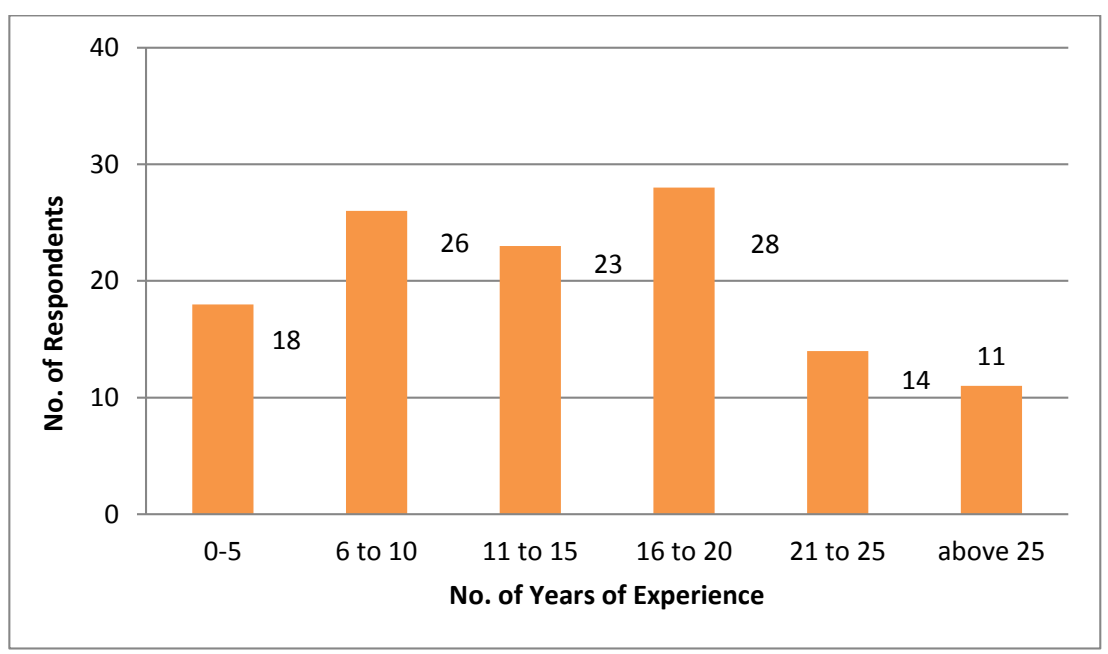

Fig. (2). Respondents' years of experience. 


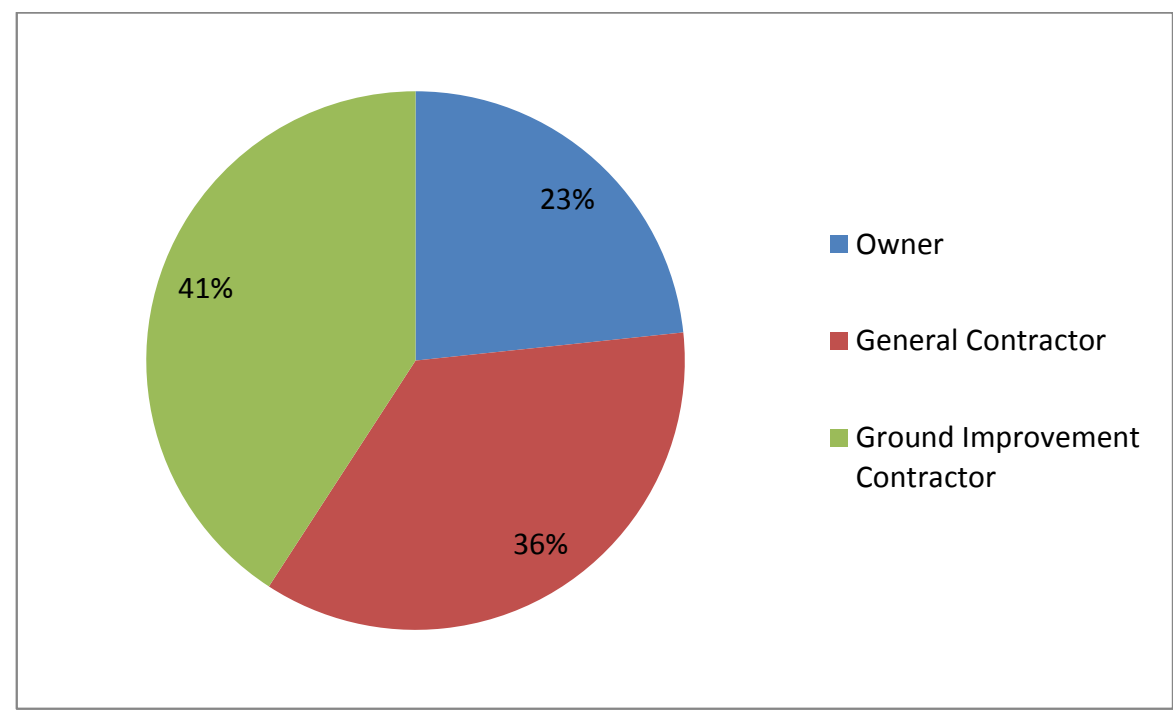

Fig. (3). Respondents' affiliations.

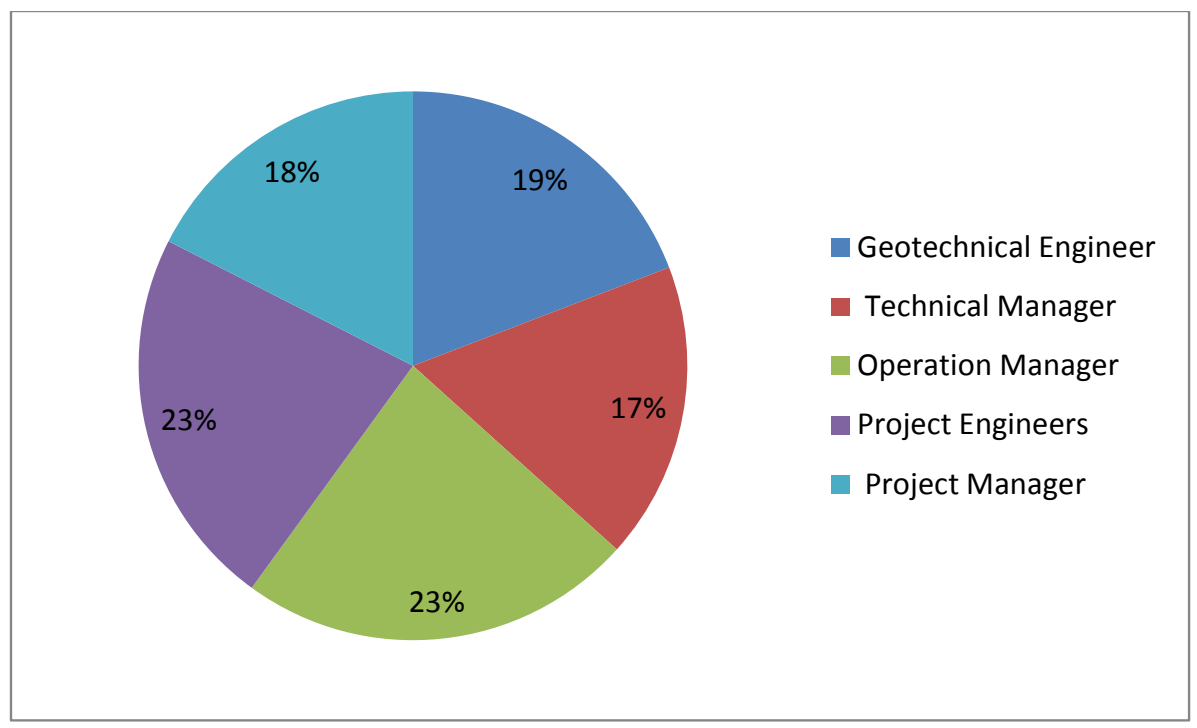

Fig. (4). Respondents by role.

Table 2 presents the results for the impact of each risk factor; the risk factor "ground improvement technique" has the highest impact according to the respondents. Table 3 shows the results of the probability of occurrence for each risk factor; the risk factor "site investigation" has the highest probability of occurrence according to respondents. The risk factor" environmental conditions" has the highest ability of detection per respondents, as shown in Table 4.

\section{Table 2. Results of the questionnaire for the impact of each risk factor.}

\begin{tabular}{|c|c|c|c|c|c|c|}
\hline $\begin{array}{c}\text { Risk Factor } \\
\text { No. }\end{array}$ & Risk Factor & $\begin{array}{c}\text { Very Low } \\
\text { Impact }\end{array}$ & Low Impact & Moderate Impact & High Impact & Very High Impact \\
\hline F. 1 & Site investigation & $2.50 \%$ & $7.50 \%$ & $16.67 \%$ & $34.17 \%$ & $39.17 \%$ \\
\hline F.2 & Ground improvement design & $5.00 \%$ & $11.67 \%$ & $15.00 \%$ & $31.67 \%$ & $36.67 \%$ \\
\hline F.3 & Environmental conditions & $6.67 \%$ & $21.67 \%$ & $25.00 \%$ & $25.00 \%$ & $21.67 \%$ \\
\hline F.4 & Ground improvement technique & $2.50 \%$ & $7.50 \%$ & $3.33 \%$ & $31.67 \%$ & $55.00 \%$ \\
\hline F.5 & Ground Improvement Performance Criteria & $18.33 \%$ & $23.33 \%$ & $25.00 \%$ & $25.00 \%$ & $8.33 \%$ \\
\hline
\end{tabular}


Table 3. Results of the questionnaire for the probability of occurrence of each risk factor.

\begin{tabular}{|c|c|c|c|c|c|c|}
\hline $\begin{array}{c}\text { Risk } \\
\text { Factor No. }\end{array}$ & Risk Factor & $\begin{array}{c}\text { Very Low } \\
\text { Probability }\end{array}$ & Low Probability & $\begin{array}{c}\text { Moderate } \\
\text { Probability }\end{array}$ & High Probability & $\begin{array}{c}\text { Very High } \\
\text { Probability }\end{array}$ \\
\hline F.1 & Site investigation & $1.67 \%$ & $6.67 \%$ & $10.00 \%$ & $38.33 \%$ & $43.33 \%$ \\
\hline F.2 & Ground improvement design & $7.50 \%$ & $15.83 \%$ & $15.83 \%$ & $28.33 \%$ & $32.50 \%$ \\
\hline F.3 & Environmental conditions & $6.67 \%$ & $16.67 \%$ & $24.17 \%$ & $25.00 \%$ & $27.50 \%$ \\
\hline F.4 & Ground improvement technique & $5.00 \%$ & $13.33 \%$ & $20.00 \%$ & $33.33 \%$ & $28.33 \%$ \\
\hline F.5 & $\begin{array}{c}\text { Ground Improvement Performance } \\
\text { Criteria }\end{array}$ & $13.33 \%$ & $22.50 \%$ & $25.00 \%$ & $29.17 \%$ & $10.00 \%$ \\
\hline
\end{tabular}

Table 4. Results of the questionnaire for the ability of detection for each risk factor.

\begin{tabular}{|c|c|c|c|c|c|c|}
\hline $\begin{array}{c}\text { Risk Factor } \\
\text { No. }\end{array}$ & Risk Factor & $\begin{array}{c}\text { Very Low } \\
\text { Detection }\end{array}$ & Low Detection & $\begin{array}{c}\text { Moderate } \\
\text { Detection }\end{array}$ & High Detection & $\begin{array}{c}\text { Very High } \\
\text { Detection }\end{array}$ \\
\hline F.1 & Site investigation & $6.67 \%$ & $20.00 \%$ & $34.17 \%$ & $28.33 \%$ & $10.83 \%$ \\
\hline F.2 & Ground improvement design & $12.50 \%$ & $20.83 \%$ & $32.50 \%$ & $22.50 \%$ & $11.67 \%$ \\
\hline F.3 & Environmental conditions & $2.50 \%$ & $9.17 \%$ & $25.00 \%$ & $29.17 \%$ & $34.17 \%$ \\
\hline F.4 & Ground improvement technique & $10.00 \%$ & $18.33 \%$ & $25.83 \%$ & $25.83 \%$ & $20.00 \%$ \\
\hline F.5 & $\begin{array}{c}\text { Ground Improvement Performance } \\
\text { Criteria }\end{array}$ & $8.33 \%$ & $20.00 \%$ & $20.83 \%$ & $27.50 \%$ & $23.33 \%$ \\
\hline
\end{tabular}

Fig. (5) summarizes the results of the questionnaire for the impact of each risk factor on the ground improvement projects. It can be noted that the average impact for risk factor F.1 (site investigation) is four, which is the highest among all risk factors, while risk factor F.5 (ground improvement performance criteria) has the lowest impact among all factors. Therefore, respondents ranked F.1 as the risk factor, which has the highest impact.

Fig. (6) presents the results of the questionnaire for the probability of occurrence of each risk factor. The results showed that the average probability of occurrence for risk factor F.1 (site investigation) is 4.15 , which is the highest among all risk factors, while risk factor F.5 (ground improvement performance criteria) has the lowest probability of occurrence among all factors. Hence, respondents ranked F.1 as the risk factor, which has the highest probability of occurrence.

Fig. (7) shows the results of the questionnaire for the ability of detection for each risk factor. The results demonstrated that the average ability of detection for risk factor F.3 (environmental conditions) is 3.83, which is the highest among all risk factors, while risk factor F.2 (ground improvement design) has the lowest ability of detection among all factors. Consequently, respondents ranked F.3 as the risk factor, which has the highest ability of detection.

Responses' Score (R.S.) was calculated for each question by dividing the average answers of each question by five, the max response value. R.S. was also calculated for each risk factor by multiplying the R.S. values of the questions of that factor by each other. Fig. (8) presents the results of the R.S. for all risk factors. It can be noted that risk factor F.1 has the highest R.S. while F.5 has the lowest. However, risk factor F.4 (ground improvement technique) has an R.S. value close to F.1 (0.41). Based on R.S. values, F.1 and F.4 are ranked first and second risk factors, respectively. This means that ground improvement specialists should pay more attention to the site investigation and the ground improvement technique in order to reduce the risk of delay and cost overrun and to achieve the project requirements.

Further analysis of the results was conducted by calculating the Risk Priority Number (RPN). Values were calculated for each risk factor by multiplying the average answers of each question by each other for that factor. Fig. (9) presents the results of the RPN calculations for all risk factors. It can be seen that F.1 has the highest RPN and F.5 the lowest. Moreover, risk factor F.4 (ground improvement technique) has the second-highest RPN value. Based on RPN values, F.1 and F.4 are ranked first and second risk factors, respectively.

The above results and analysis indicate that ground improvement specialists should pay closer attention to the site investigation and the ground improvement technique to minimize the risk of delay and cost overruns and maximize the possibility of fulfilling project requirements.

Respondents were asked to provide suggestions to mitigate risk factors. Those suggestions were studied and summarized in Table 5. 


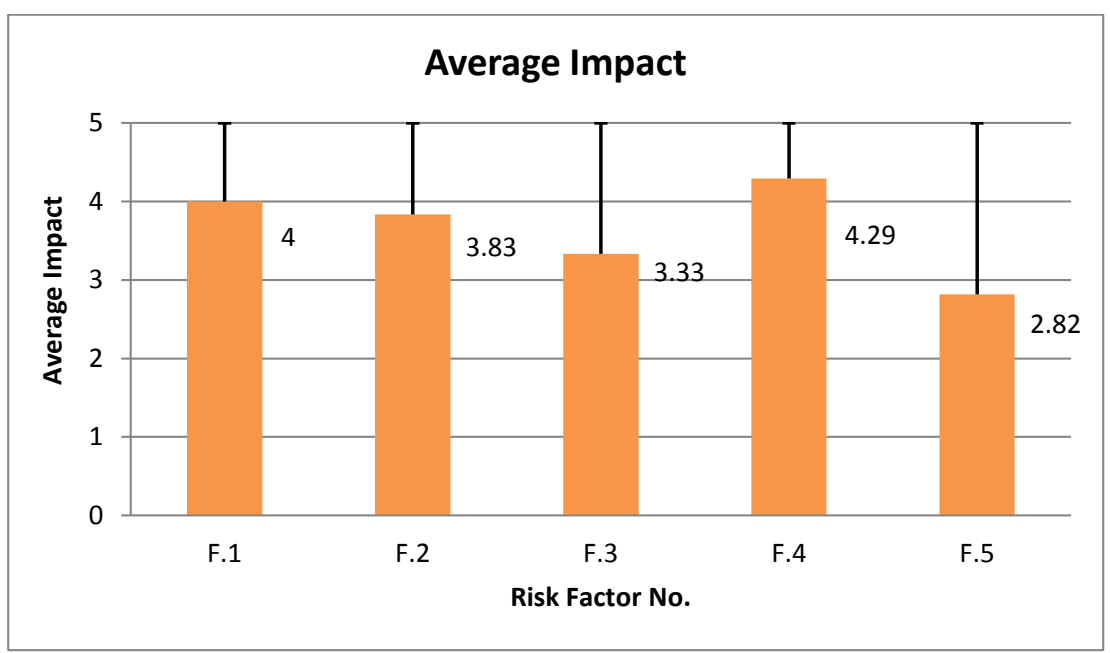

Fig. (5). Average impact of each risk factor.

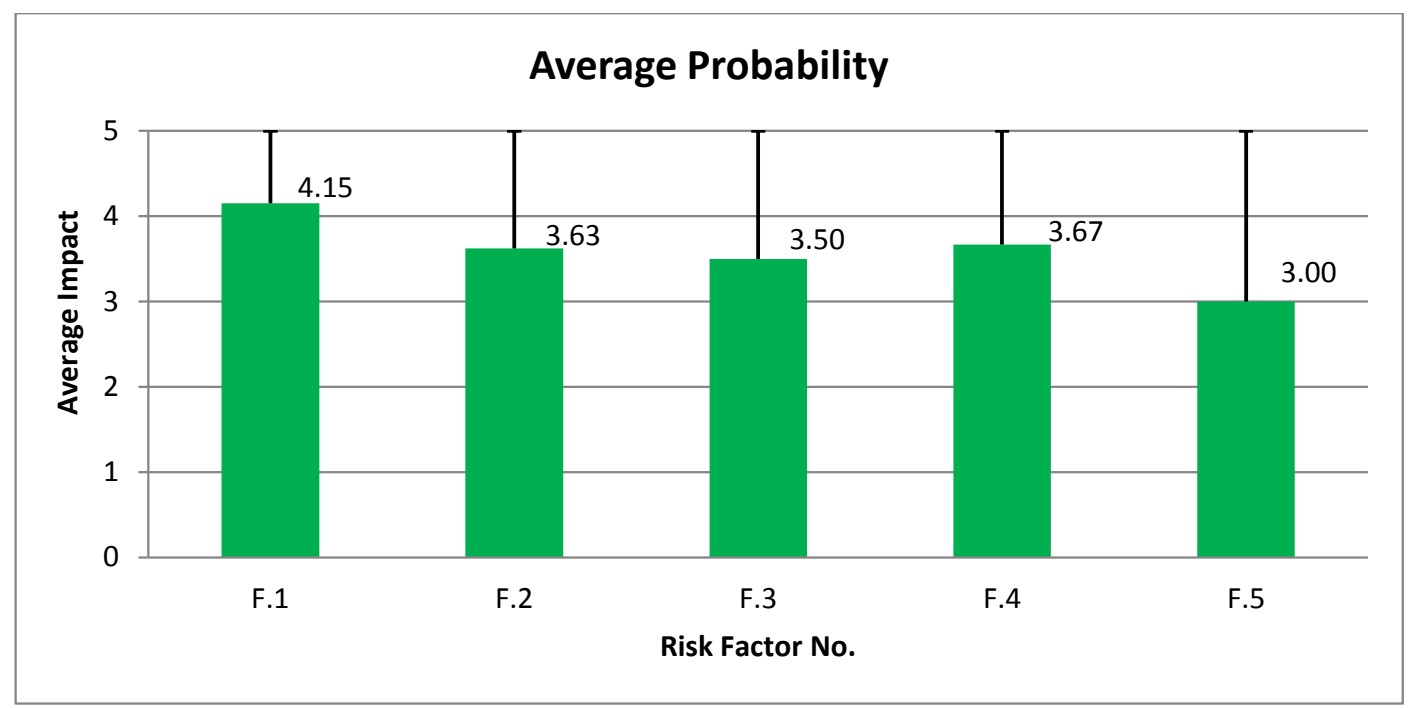

Fig. (6). Average probability of occurrence of each risk factor.

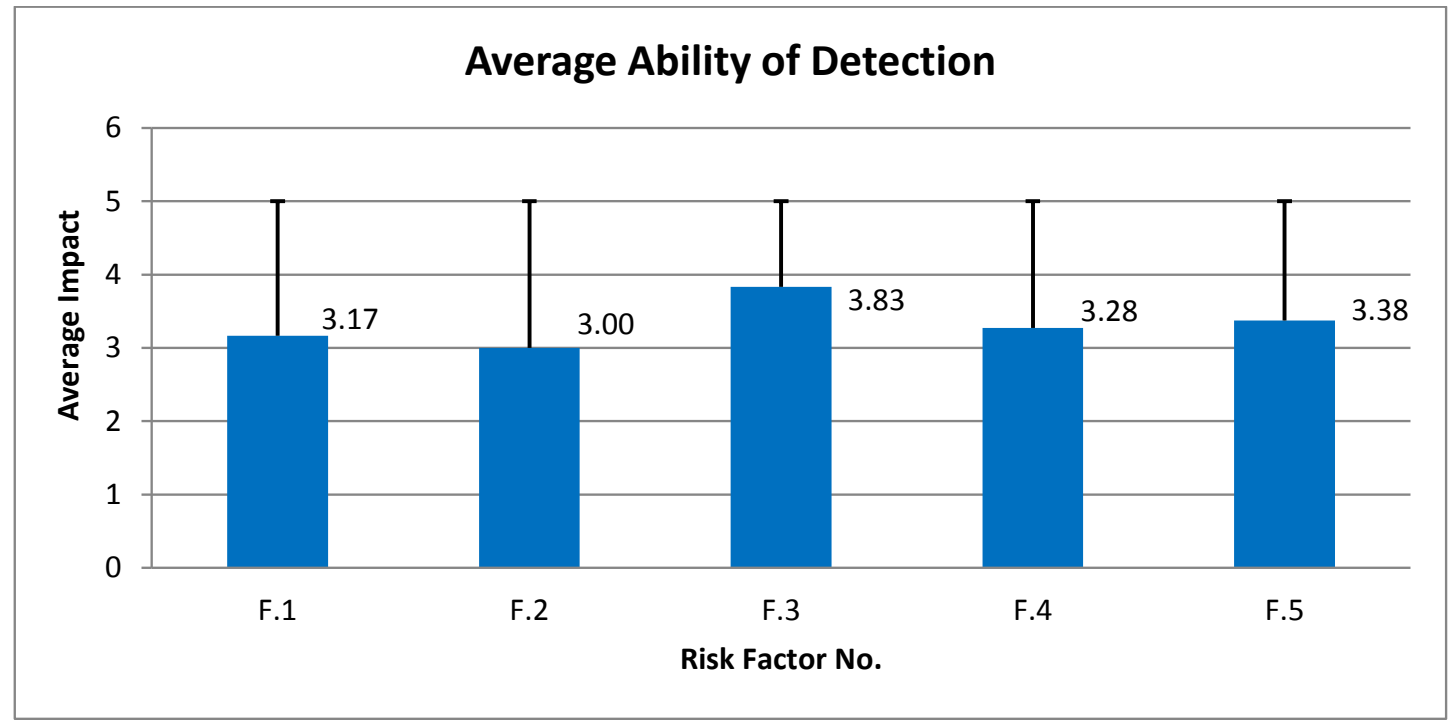

Fig. (7). Average ability of detection for each risk factor. 


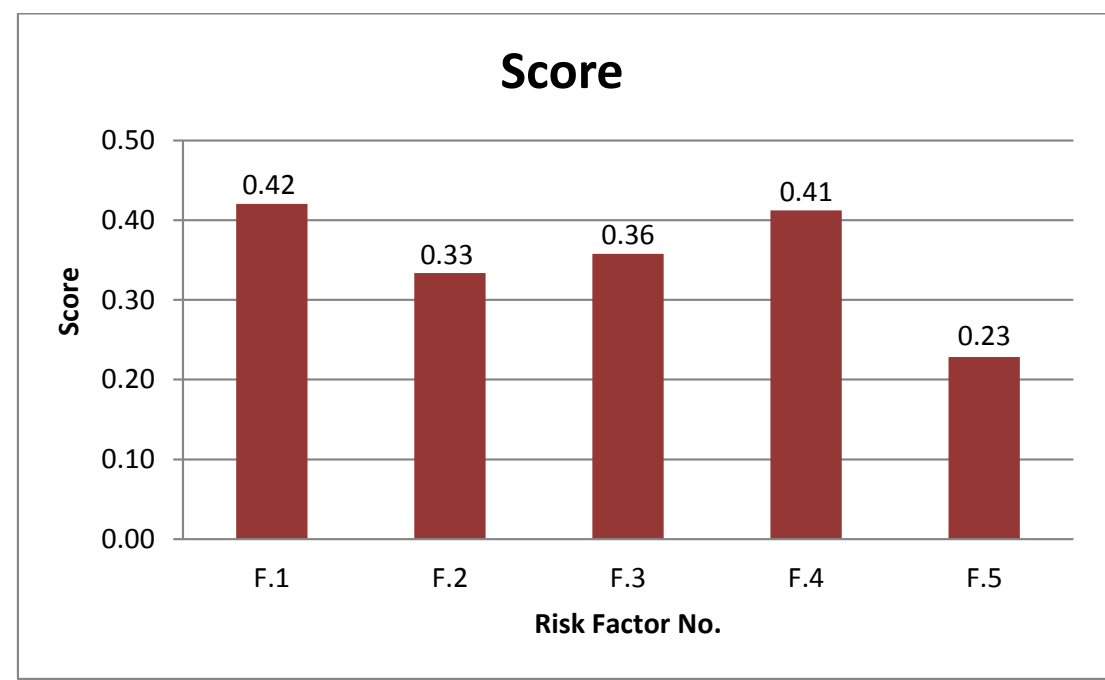

Fig. (8). Responses' score for each risk factor.

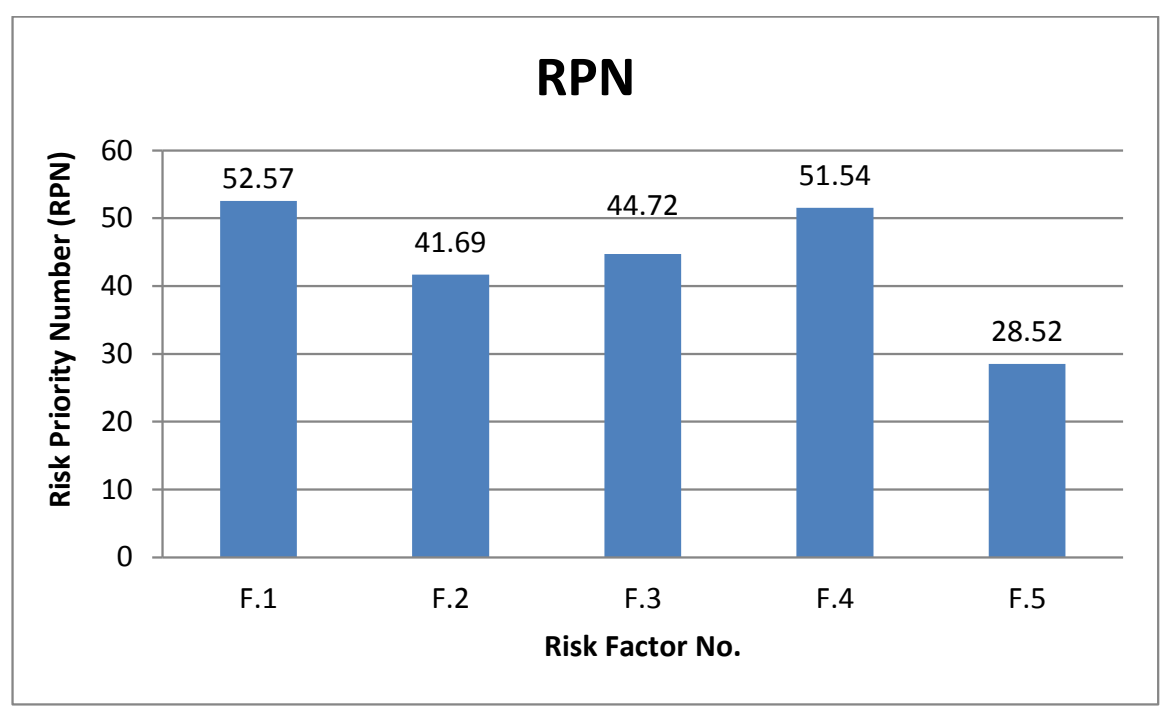

Fig. (9). Risk Priority Number (RPN) for each risk factor.

Table 5. Proposed Risk Mitigation.

\begin{tabular}{|c|c|c|}
\hline $\begin{array}{c}\text { Rack } \\
\text { No. }\end{array}$ & \multicolumn{1}{|c|}{ Risk Factor } & Proposed Mitigation \\
\hline F.1 & Site investigation & $\begin{array}{l}\text { - Ground Improvement Contractors (GIC) should have detailed information about the soil profile of the } \\
\text { project site. } \\
- \text { GIC should perform their own site investigation in case of missing soil information. }\end{array}$ \\
\hline F.2 & Ground improvement design & $\begin{array}{l}\text { - GIC should use accurate soil information to provide detailed design for the ground improvement work } \\
\text { before commencement of work. } \\
- \text { The design should include a detailed plan on work procedure and schedule. }\end{array}$ \\
\hline F.3 & Environmental conditions & $\begin{array}{l}\text { - Construction work activities are not allowed during the summer season (June to September) from } \\
12: 00 \text { to } 3: 00 \text { PM due to the hot weather. Also, the number of working hours is reduced during the holy } \\
\text { month of Ramadan. Therefore, number of working hours should be adjusted. } \\
\bullet \text { Water table is usually shallow in the GCC. This factor should be considered when using heavy } \\
\text { equipment. }\end{array}$ \\
\hline
\end{tabular}




\begin{tabular}{|c|c|c|}
\hline F.4 & $\begin{array}{c}\text { Ground improvement } \\
\text { technique }\end{array}$ & $\begin{array}{l}\text { - GIC should select an appropriate and feasible ground improvement technique to reduce the cost. } \\
\text { - They can use different techniques at the same project site depending on the soil profile. } \\
\text { - GIC should pay attention to any nearby structures at project site because heavy equipment produces } \\
\text { vibration that may cause damage to structures. For example, Dynamic Compaction (DC) and Dynamic } \\
\text { Replacement (DR) produce high peak particle velocity that may cause damage to structures. } \\
\text { - When using techniques that require inclusion of granular soils, the cost of this material should be } \\
\text { included. }\end{array}$ \\
\hline F.5 & $\begin{array}{l}\text { Ground improvement } \\
\text { performance criteria }\end{array}$ & $\begin{array}{l}\text { - GIC should have a good understanding of the required performance criteria. } \\
\text { - The criteria should be part of the bidding documents to avoid any conflict. } \\
\text { - The cost should include all required testing programs to meet the criteria. }\end{array}$ \\
\hline
\end{tabular}

\section{SUMMARY AND CONCLUSION}

A questionnaire was used to determine the possible risk factors that affect the ground improvement projects in the GCC. Data were collected using a questionnaire completed by 120 respondents who work in the ground improvement industry in the GCC. Responses were analyzed using descriptive statistics, R.S., and RPN. Five risk factors were included in the ques-tionnaire: site investigation, ground improvement technique, environmental conditions, ground improvement design, and ground improvement performance criteria.

In terms of the impact on the project and probability of occurrence, respondents ranked the site investigation as the top risk factor and ground improvement performance criteria as the last.

The high and very high probability of occurrence for the site investigation risk factor is 38.33 and $43.33 \%$, respectively. It should be noted that site investigation gives detail information about the soil type, strength, depth of layers, and level of water.

Respondent ranked environmental conditions as the top risk factor when it comes to the ability of detection $(28.33 \%$ and $34.1 \%$ for the high and very high detection, respectively) and the ground improvement design as the last. The GCC environmental conditions mainly refer to the high temperature during the summer, and this limits the working hours during the day time.

The site investigation has the highest R.S. and RPN values, while the ground improvement performance criteria have the lowest.

Ground improvement specialists should pay more attention to the site investigation, to the evaluation of soil conditions, and to the selection of ground improvement techniques to reduce the risk of delay, harm to quality, increases in costs, and failure to achieve the project design requirements. Table $\mathbf{5}$ provides detailed recommendations to mitigate each risk factor.

\section{CONSENT FOR PUBLICATION}

Not applicable.

\section{AVAILABILITY OF DATA AND MATERIALS}

The data supporting the findings of this article are available within this paper.

\section{FUNDING}

None.

\section{CONFLICT OF INTEREST}

The authors declare no conflicts of interest, financial or otherwise.

\section{ACKNOWLEDGEMENTS}

Declared none.

\section{REFERENCES}

[1] T. Uher, and A.S. Zantis, Programming and scheduling techniques., Spon Press: Oxford, U.K., 2012. [http://dx.doi.org/10.4324/9780203836002]

[2] J. Menezes Jr, C. Gusmão, and H. Moura, "Defining indicators for risk assessment in software development projects", CLEI Electr. J., vol. 16, no. 1, pp. 11-11, 2013.

[http://dx.doi.org/10.19153/cleiej.16.1.10]

[3] D. San Santoso, S.O. Ogunlana, and T. Minato, "Assessment of risks in high rise building construction in Jakarta", Eng. Construct. Architect. Manag., vol. 10, no. 1, pp. 43-55, 2003. [http://dx.doi.org/10.1108/09699980310466541]

[4] C. Chapman, and C. Ward, Managing project risk and uncertainty: A constructively simple approach to decision making., Wiley: Chichester, U.K, 2002.

[5] J. Raftery, Risk analysis in Project Management., E\&FN Spon: London, U.K., 1999.

[6] E. Zio, and T. Aven, "Model output uncertainty in risk assessment", Int. J. Perform. Eng., vol. 29, no. 5, pp. 475-486, 2013.

[7] A. Altoryman, Identification and assessment of risk factors affecting construction projects in the Gulf region: Kuwait and Bahrain., 2014.

[8] A. Cerić, D. Marčić, and M.S. Kovačević, "Applying the analytic network process for risk assessment in sustainable ground improvement", Gradevinar, vol. 65, no. 10, pp. 919-929, 2013. [http://dx.doi.org/10.14256/JCE.841.2013]

[9] B. Tarawneh, "Decision tree for the selection of appropriate ground improvement technique in the arabian gulf region",

[10] I.M. Crawford, Marketing Research., Centre for agricultural marketing training in eastern and southern africa: Harare, Zimbabwe, 1990.

[11] J.M. Converse, and S. Presser, Survey questions: Handcrafting the standardized questionnaire., Sage: California, USA, 1986. [http://dx.doi.org/10.4135/9781412986045]

[12] P. McNeil, Research Methods., Routledge: London, U.K, 1990.

[13] A.N. Oppenhein, Questionnaire design, interviewing and attitude measurement., Pinter: London, U.K., 1992.

[14] S. Ghosh, and J. Jintanapakanont, "Identifying and assessing the 
critical risk factors in an underground rail project in Thailand: a factor analysis approach", Int. J. Proj. Manag., vol. 22, no. 8, pp. 633-643,
2004.

[http://dx.doi.org/10.1016/j.ijproman.2004.05.004]

\section{C) 2020 Tarawneh \& Al Ajmi}

This is an open access article distributed under the terms of the Creative Commons Attribution 4.0 International Public License (CC-BY 4.0), a copy of which is available at: https://creativecommons.org/licenses/by/4.0/legalcode. This license permits unrestricted use, distribution, and reproduction in any medium, provided the original author and source are credited. 